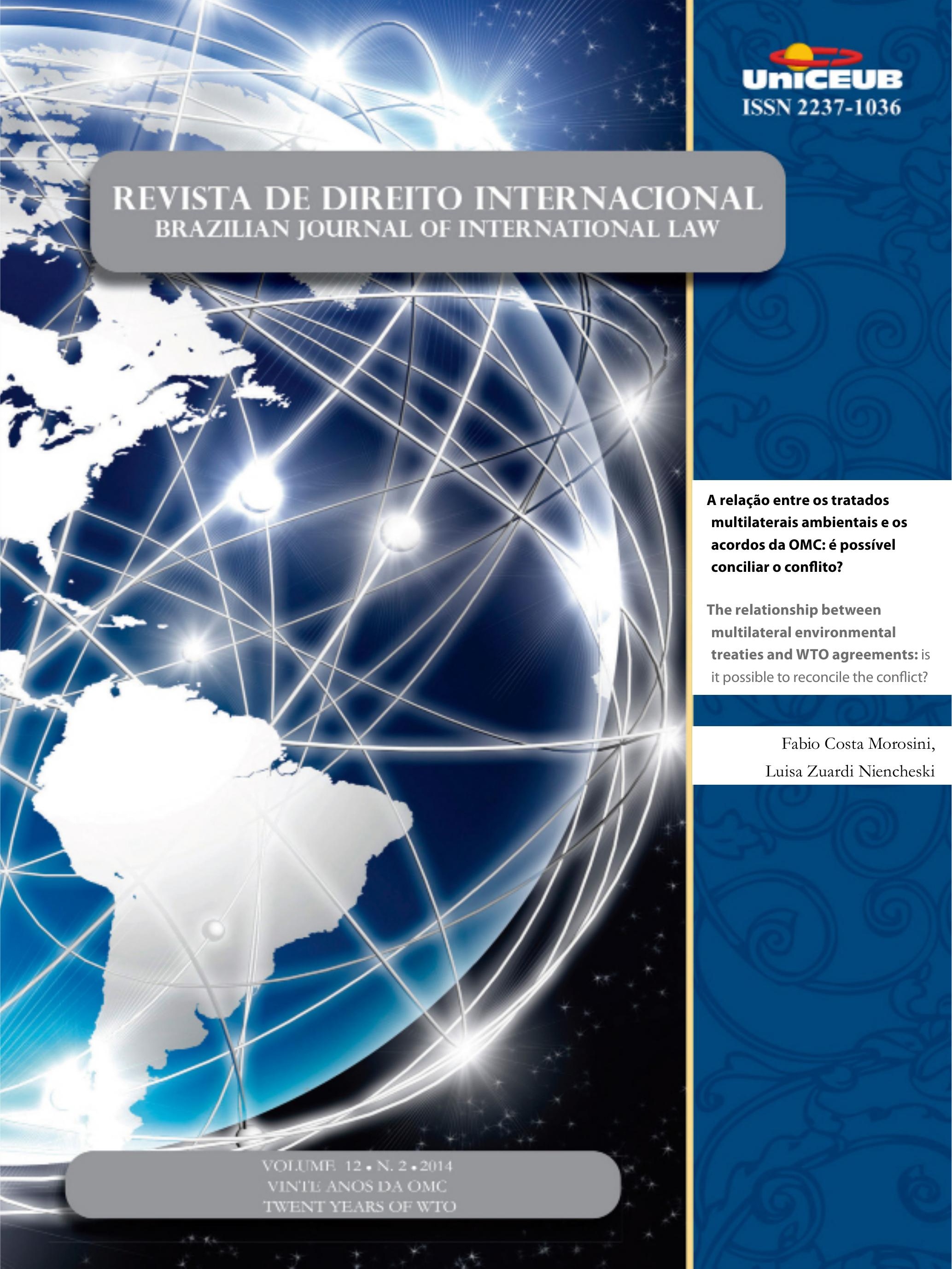




\title{
A relação entre os tratados multilaterais ambientais e os acordos da OMC: é possível conciliar o conflito?*
}

\author{
The relationship between multilateral \\ environmental treaties and WTO agreements: is it \\ possible to reconcile the conflict?
}

\author{
Fabio Costa Morosini, ${ }^{* *}$ \\ Luisa Zuardi Niencheski***
}

\section{Resumo}

A partir da repartição sistêmica interna do ordenamento jurídico internacional, consolidando-se de certa forma a independência dos regimes ambiental e comercial, potencializa-se a concorrência de jurisdições competentes para solucionar os conflitos, bem como a aplicação desconexa de diferentes normas que tutelam interesses comuns da sociedade. Nesse espectro, o presente artigo objetiva verificar o fenômeno que surge quando normas dos tratados multilaterais ambientais, que estipulam restrições comerciais, conflitam com a questão da ampliação do comércio internacional, mormente violando os princípios nucleares da OMC da cláusula da nação mais favorecida e do tratamento nacional. Assim, por meio da análise de tratados internacionais, de jurisprudência e de revisão bibliográfica, demonstrar-se-á que as disposições dos tratados ambientais e comerciais interagem no cenário jurídico internacional, denunciando que o sistema de livre-comércio inclina-se a adaptar a agenda ambiental entre as suas preocupações.

Palavras-chave: OMC. Tratados Multilaterais Ambientais. Conflito. Convenção de Viena sobre Direito dos Tratados. Artigo XX do GATT.

\footnotetext{
* Recebido em 22.10.2014

Aceito em 23.11.2014
}

\section{Abstract}

The internal systemic breakdown of the international legal order consolidates the independence of environmental and trade regimes and enhances competition of competent courts to resolve conflicts as well as imply the application of different rules that safeguard common interests of society. Thereby, the reading that follows aims to verify the phenomenon that arises when rules of multilateral environmental agreements stipulating trade restrictions conflict with the question of the expansion of international trade, especially because it violates the principles of the most favored nation and national treatment of WTO. Through the analysis of international law and treaties literature review, this study concludes that the provisions of environmental and trade agreements interact in the international legal scene, denouncing that the system of free trade is leaning to adapt the environmental agenda between their concerns.

Keywords: WTO. Multilateral Environmental Agreements. Conflict; Vienna Convention on the Law of Treaties. GATT Article XX. 
I. Crônicas

1. Crônicas da atualidade do Direito Internacional ......................................................16

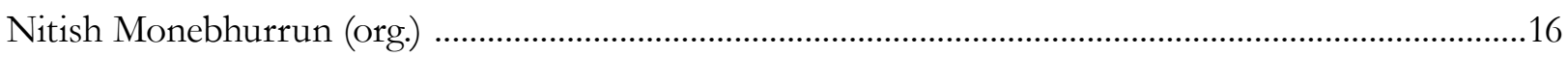

2.Decisões da Corte Internacional de Justiça e do Tribunal Internacional Sobre o Direito do Mar

Nitish Monebhurrun

José Eduardo Siqueira

3. Crônicas do direito internacional dos inVestimentos

Nitish Monebhurrun

\section{Os Vinte Anos dA OMC}

EXPORT CONTROLS AS INDUSTRIAL POLICY ON NATURAL RESOURCES: REGULATORY LIMITATIONS ON CHINA - RAW MATERIALS AND CHINA - RARE EARTHS CASES.

Gustavo Ferreira Ribeiro

O problema da espionagem econômica internacional: Seria a Organização Mundial do CoMÉRCIO O FORO ADEQUADO PARA SUA APRECIAÇÃO?

Humberto A.Vasconcelos Lima

Naiana Magrini Rodrigues Cunha

International Standards for Intellectual Property Rights Protection: a reflection on CLIMATE-FRIENDLY TECHNOLOGY TRANSFER.

Guihong Zhang

Jiani Jiang

Can Wang

Os vinte anos da OMC, suas conquistas e desafios: uma análise do Brasil e o Sistema de SoLUÇõES DE CONTROvÉRsias

Etiene M. Bosco Breviglieri

Luciano Meneguetti Pereira

A relação entre os tratados multilaterais ambientais e os acordos da OMC: é possível CONCILIAR O CONFLITO?

Fabio Costa Morosini,

Luisa Zuardi Niencheski 
Um desafio na Organização Mundial do Comércio: viabilidade de um aCordo Plurilateral

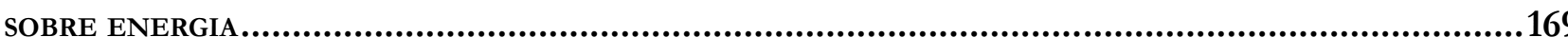

Matheus Linck Bassani

CONTRATAÇÕES PÚBLICAS NO ÂMBITO DA OMC: A POLÍTICA LEGISLATIVA BRASILEIRA À LUZ DO DIREITO AO DESENVOLVIMENTO 192

André Jansen do Nascimento

GovernanÇa global e a Organização Mundial do Comércio: Desafios impostos Pelo novo MANDATO DE DESENVOLVIMENTO

Letícia de Souza Daibert

Ana Luísa Soares Peres

Vinte Anos de Crise para a África? Poder, Assimetrias e a Abordagem Liberal da OMC.....239 Igor Abdalla Medina de Souza

Os MECANISMos DE INDUÇão AO CUMPRIMENTO NO ÂMBITO DA OMC

Fernando Lopes Ferraz Elias

A promoção de accountability na Organização Mundial do Comércio: uma análise hori-

Celso Henrique Cadete de Figueiredo

LA OMC Y EL PROCESO DE GLOBALIZACION DE LA REGULACIÓN ALIMENTARIA

Maria Eugenia Marichal

O ACORDO GATS E SUA APLICAÇÃO AOS SERVIÇOS DO COMÉRCIO ELETRÔNICO

Gleisse Ribeiro Alves

A OMC E O REGIONALISMo do SÉCULO XXI: ESTRATÉGIA DE IMPOSIÇÃo DE MODELOS NORMATIVOS? .. 337 Camilla Capucio

A ORganizaÇão MUNDIAL do COMÉRCIO E A CHINA: DIREITO DE PROPRIEDADE E PROPRIEDADE INTELECTUAL NO PAÍS

Dos contenciosos na OMC COM ENFOQue EM RESTRIÇÕES Às EXPORTAÇõEs DA China 363

Marco Antônio Alcântara Nascimento 
O redimensionamento da OMC no trato dos Acordos Comerciais Regionais

Alice Rocha da Silva

\section{Outros Temas}

Derechos Humanos en la Realidad actual: la globalización y el multiculturalismo

David Falcão

IMUNIDADE DE JURISDIÇÃo DO EsTADO E REPARAÇÃo CIVIL PELA PRÁTICA DE TORTURA: O CASO ZAHRA KAZEMI V. REPÚBLICA ISLÂMICA do Irã

Patrícia Maria Lara Abreu

Rodrigo Otávio Bastos Silva Raposo

INTERREGIONAL ORgANIZATIONS (IROS) IN EUROPE: NEW SUBJECTS OF CONTEMPORARY INTERNATIONAL LAW?

Davorin Lapas

A CONEXÃo ENTRE OS DIREITOS HUMANOS E A CORRUPÇÃo

Gabriela Alves Mendes Vieira

Marcelo Dias Varella

GRUPO DE SOCIEDADES: INSTRUMENTO JURÍDICO DE ORGANIZAÇÃO DA EMPRESA PLURISSOCIETÁRIA.....495

Daniel Amin Ferraz 


\section{Introdução}

A partir da especificação dos subsistemas ambiental e comercial, o processo de internacionalização do direito deflagrou a emergência de um fenômeno constatado quando normas dos tratados multilaterais ambientais entram em atrito com normas da OMC. A expansão de normas que ditam a lógica do comércio internacional e da proteção ao meio ambiente coexiste no espaço do direito internacional, mas, em circunstâncias particulares, revelam a probabilidade da disrupção de conflitos.

$\mathrm{O}$ risco de colisão entre situações que objetivam um sistema multilateral de comércio aberto, previsível, equitativo e não discriminatório sem conjugar os valores do desenvolvimento sustentável deve ser evitado ao extremo. No mesmo passo, tratados multilaterais ambientais deveriam enquadrar suas cláusulas de forma a promover a distribuição ótima da produção mundial consoante vantagens comparativa e beneficiando parceiros comerciais. Enquanto o sistema jurídico não garantir a certeza e a igualdade de tratamento à coexistência dessas normas incompatíveis, a proliferação de conflitos tende a agravar.

A fim de demonstrar que os órgãos jurisdicionais da OMC, Painel e Órgão de Apelação, podem utilizar outros instrumentos do direito internacional para realizar uma interpretação efetiva de suas decisões e, assim, evitar a concorrência normativa e jurisdicional entre os regimes ambiental e comercial, o artigo é dividido em 3 partes, cada qual comportando 2 subdivisões.

Desta forma, tendo como ponto de partida a definição do conceito de conflito e a incidência de seus tipos (conflito de jurisdições e conflito de normas), ${ }^{1}$ o artigo explica as interações entre as normas que compõem o subsistema do comércio e as do direito ambiental, verificando como o Painel e Órgão de Apelação podem incorporar disposições alienígenas aos acordos constitutivos da OMC. Nesse propósito, as regras de interpretação do artigo 31 da Convenção de Viena sobre Direito dos Tratados e aplicação de princípios, como o do desenvolvimento sustentável e da transparência, são pontos-chave nesta análise. Por derradeiro, com o intuito de ressaltar de que maneira é possível a coexistência mútua de tais normas, procede-

1 MARCEAU, Gabrielle. Conflicts of Norms and Conflicts of Jurisdictions: The Relationship between the WTO Agreement and MEAs and other Treaties. Journal of World Trade, Holanda, v. 35, n. 6, p. 1081-1131, 2001. se ao exame do artigo XX do GATT, exemplificandose o progresso do tratamento das causas ambientais por meio de casos levados a julgamento pelo GATT e, atualmente, pela OMC.

\section{Obstáculo para superação: análise do surgimento de conflitos}

\subsection{Conflito de normas}

As normas a respeito do comércio internacional e do meio ambiente apresentam finalidades muito específicas, dentro de seus regimes, e dependem de medidas que podem, muitas vezes apontar para direções conflitantes. No âmbito da presente discussão, a existência de um conflito condiciona-se ao estabelecimento de uma disposição nos acordos da OMC que terminantemente proíba uma obrigação expressa em tratado ambiental multilateral ou viceversa. A concorrência entre normas relaciona-se com situações em que obrigações dispostas em mais de um tratado não podem ser reconciliadas.

Isto porque diversos tratados ambientais passaram a dispor de sanções para prevenir a comercialização sobre alguns bens nocivos ao ambiente, autorizando certos Estados - a pretexto de salvaguardarem o meio ambiente - a discriminar produtos estrangeiros em comparação com os locais.

Essa atitude estaria por violar o princípio da não discriminação entre Estados membros da OMC, expresso nas cláusulas da nação mais favorecida e do tratamento nacional, tornando-se inegável o possível conflito entre esses tratados e os acordos da OMC. O princípio da nação mais favorecida (artigo I do GATT) ${ }^{2}$ proíbe a discriminação de um mesmo produto por parte dos diferentes países exportadores, enquanto que o princípio do tratamento nacional (artigo III do GATT) ${ }^{3}$

2 Especificamente, o artigo I:1 do GATT de 1994 dispõe que qualquer vantagem, benefício, privilégio ou imunidade concedida por qualquer membro a qualquer produto originado em ou destinado a qualquer outro país será conferido imediatamente e automaticamente aos produtos equivalentes originados em ou destinados aos territórios de todos os outros membros. O objetivo da obrigação de tratamento da nação mais favorecida é, então, assegurar igualdade de oportunidades para importar de ou exportar para todos os Membros da OMC. Nesse sentido, ver: UNITED NATIONS. Solução de Controvérsias. Conferência das Nações Unidas para o Comércio e Desenvolvimento. Nações Unidas, Nova Iorque e Genebra. 2003. Disponível em: <http://unctad.org/pt/docs/ edmmisc232add16_pt.pdf>. Acesso em: 18 jun. 2012.

3 O princípio do tratamento nacional, estipulado no artigo III 
proíbe discriminação entre produtos produzidos internamente e o mesmo tipo de produto importado, prevenindo práticas estatais para ilidir tributos e outras obrigações comerciais. Em algumas ocasiões, para que a norma seja eficiente, ocorre o afastamento com o que foi anteriormente previsto nos princípios gerais do direito internacional, questionando-se a unidade do ordenamento jurídico internacional.

Tal situação inicia-se quando medidas unilaterais são adotadas pelos Estados com o intuito de resguardar os recursos naturais e promover a preservação no contexto internacional. Algumas dessas medidas, constantes nos tratados multilaterais ambientais, dispõem sobre valores incompatíveis com o subsistema comercial, impondo suas normas mesmo a Estados não partes da OMC.

Em relação ao conflito de normas, Marceau ${ }^{4}$ explica que a existência de um conflito entre dois tratados depende de três condicionantes. Primeiro, que dois Estados assumam compromissos recíprocos em dois diferentes tratados. Em segundo, ambos os tratados devem ter pontos de contato, isto é, cobrirem o mesmo assunto, caso contrário não haveria nenhuma possibilidade de conflito. Terceiro, as disposições devem entrar em conflito no sentido de que devem impor obrigações mutuamente exclusivas.

Pauwelyn ${ }^{5}$, Kelly $^{6}$ e Bartels ${ }^{7}$ são adeptos da teoria de que conflito é sinônimo da incompatibilidade,

do GATT estabelece que "os membros reconhecem que tributos internos e outros encargos internos, e leis, regulamentos e requisitos que afetem a venda interna, oferta para venda, compra,transporte, distribuição ou uso de produtos, e regulamentações quantitativas internas que requeiram a mistura, processamento ou uso de produtos em quantidades ou proporções especificadas, não devem ser aplicados a produtos importados ou domésticos de modo a conferir proteção à produção doméstica". Dessa forma, o objetivo deste princípio é proibir a discriminação entre produtos domésticos e produtos importados similares. Nesse sentido, ver: UNITED NATIONS. Solução de Controvérsias. Conferência das Nações Unidas para o Comércio e Desenvolvimento. Nações Unidas, Nova Yorque e Genebra. 2003. Disponível em: <http://unctad.org/pt/docs/ edmmisc232add16_pt.pdf $>$. Acesso em: 18 jun. 2012.

4 MARCEAU, Gabrielle. Conflicts of norms and conflicts of jurisdictions: the relationship between the WTO agreement and MEAs and other treaties. Journal of World Trade, Holanda, v. 35, n. 6, p. 1084, 2001.

5 PAUWELYN, Joost. Conflict of norms in public international law: how wto law relates to other rules of international law. New York: Cambridge University Press, 2003. p. 169.

6 KELLY, Claire. The value vacuum: self-enforcing regimes and the dilution of the normative feedback loop. Michigan Journal of International Law. v. 22, p. 674, 2001.

7 BARTELS, Lorand. Jurisdiction and applicable law clauses: where does a tribunal find the principal norms applicable to the da inconsistência ou da contradição entre normas, designando também o conflito entre as disposições de um tratado ratificado posteriormente que viole o tratado anterior ou vice-versa. Segundo este viés mais amplo, ${ }^{8}$ tal situação de conflito ganha visibilidade quando, por exemplo, um tratado multilateral a mbiental concede a prerrogativa de impor restrições ao comércio de produtos específicos e que, em contrapartida, seria proibida em violação à cláusula da nação mais favorecida disposta no artigo III do GATT/OMC. O Painel da OMC, ao julgar o caso EC - Bananas $I I I,{ }^{9}$ expressou seu alinhamento ao enfoque não restrito de conflito, exigindo 2 situações para a instauração do conflito: haver o confronto de obrigações mutuamente exclusivas e haver uma norma que é proibida em um acordo, sendo permitida em outro.

A Comissão deDireito Internacional, acompanhando essa doutrina, examina o conceito de conflito sob as perspectivas do objeto, das questões jurídicas e das finalidades de um tratado de direito internacional. No relatório elaborado pela Comissão em 2006, afirma-se que uma definição ampla de conflito consiste em

uma situação em que duas regras ou princípios sugerem diferentes formas de lidar com um problema. Concentrar-se apenas em uma mera incompatibilidade lógica entre normas, acaba por descaracterizar o raciocínio jurídico como subsunção lógica. $\mathrm{Na}$ verdade, qualquer decisão envolve o processo de interpretação e escolha entre regras e significados alternativos que não podem ser suprimidos dentro do modelo de raciocínio lógico. ${ }^{10}$

case before it? In: BROUDE, T.; SHANY, Y. (eds). Multi-Sourced Equivalent Norms in International Law. Oxford: Hart, 2011. p. 123.

8 Cumpre ressaltar que Jenks, considerado precursor na seara do conflito internacional, define o conflito sob uma abordagem restrita como sendo a incompatibilidade direta de uma parte signatária de dois tratados adimplir obrigações constantes em ambos os instrumentos do direito internacional. Ver em: JENKS, Wilfred. The Conflict of Law-Making Treaties. 30 British Yearbook of International Law, 1953. p. 30.

9 Relatório do Painel European Communities - Regime for the Importation, Sale and Distribution of Bananas, WT/DS27 - R, adotado pelo Órgão de Solução de Controvérsias em 22 de maio de 1997. para. 7. 159.

10 Tradução nossa de: "This Report adopts a wide notion of conflict as a situation where two rules or principles suggest different ways of dealing with a problem. Focusing on a mere logical incompatibility mischaracterizes legal reasoning as logical subsumption. In fact, any decision will involve interpretation and choice between alternative rule-formulations and meanings that cannot be pressed within the model of logical reasoning." em CDI. Comissão de Direito Internacional da Organização das Nações 
Percebe-se uma evidente incidência do conflito de normas ambientais e comerciais ao se analisar os seguintes tratados multilaterais ambientais. Apesar de existirem mais de 250 tratados multilaterais ambientais, com membros que variam de pequenos grupos até o conjunto de 180 países, apenas 20 destes acordos incluem disposições que podem influenciar e afetar o comércio, ao dispor acerca de medidas que proíbam o comércio de determinada espécie ou produto ou que permitam aos países restringir o comércio em determinadas circunstâncias. Por exemplo, a CITES estabelece rígidas regras para as licenças de importação e exportação das espécies ameaçadas, que serão concedidas em circunstâncias excepcionais. ${ }^{11}$ A Convenção Internacional de Proteção Fitossanitária, por sua vez, com o objetivo de prevenir a introdução e disseminação de pragas, dispõe que as partes contratantes poderão impor e adotar medidas que proíbam a importação de plantas e produtos vegetais. ${ }^{12}$ O Protocolo de Montreal claramente ilustra a tensão que poderá surgir com normas comerciais. Contém medidas específicas proibindo a circulação de produtos que contenham substâncias prejudiciais à camada de ozônio com Estados que não sejam partes do Protocolo. ${ }^{13}$

Neste viés, a Convenção sobre Comércio Internacional de Espécies em Extinção da Fauna e da

Unidas. United Nations. Fragmentation of International Law: difficulties arising from the diversification and expansion of international law. Report of the Study Group of the International Law Commission. Finalized by Martti Koskenniemi. April, 2006. Disponível em: <http://untreaty. un.org/ilc/documentation/english/a_cn4_1682.pdf>. Acesso em: 17 abr. 2013. p. 19.

11 Colacionam-se alguns artigos da CITES que expressam a sujeição do comércio internacional de determinadas espécies às regras protetivas do meio ambiente. Artigo II, 4: As partes signatárias não devem permitir o comércio das espécies listadas no Anexo I, II e III, salvo se estiver de acordo com as disposições da presente Convenção. Artigo III, 2. A exportação de qualquer espécie incluída no Anexo I deve preceder a concessão e apresentação de uma licença de exportação. Uma licença de exportação só será concedida quando as algumas condições forem satisfeitas. Disponível em: <http:// www.cites.org/eng/disc/text.php\#II>. Acesso em: 21 out. 2014.

12 Artigo 7 da International Plant Protection Convention estabelece que as partes devem regulamentar estritamente a importação e exportação de vegetais e produtos vegetais, através de proibições, inspeções e destruição de partidas prejudicadas. Disponível em: <https://www.ippc.int/> . Acesso em: 21 out. 2014.

13 Artigo 4 do Protocolo de Montreal afirma que: "As partes que não fizeram objeções ao texto do anexo e estiverem de acordo com estes procedimentos, deverão proibir, dentro de um ano da entrada em vigor do anexo, a importação desses produtos de qualquer Estado que não seja Parte do presente Protocolo.” Disponível em: $<$ http://ozone.unep.org/new_site/en/Treaties/treaties_decisionshb.php?nav_id=19>. Acesso em: 21 out. 2014.
Flora Silvestre (CITES, sigla em inglês),aderida pelo Brasil em 1975, prevê medidas restritivas ao comércio em diferentes níveis de instâncias de decisões cujo objetivo é impor uma regulamentação rigorosa, a fim de não colocar em risco ainda mais a sobrevivência das espécies ameaçadas da fauna e flora silvestre, excepcionando o comércio em determinadas circunstâncias (reprodução em cativeiro, reprodução artificial, pesquisa científica) e desde que não seja voltado à obtenção de benefício econômico. ${ }^{14}$

Tendo em vista que a CITES utiliza medidas comerciais para sua implementação, recomenda-se a suspensão temporária do comércio com a parte que não cumpriu com suas obrigações, concedendo-lhe tempo para enquadrar-se aos compliance mechanisms, entre os quais destaca-se a apresentação de relatórios, a promulgação da legislação adequada, o combate e a redução do comércio ilegal e o atendimento às recomendações específicas. Assim, a suspensão do comércio é considerada uma forma de precaução, ilidindo a contínua violação da Convenção, prejudicial à sobrevivência das espécies ameaçadas.

Em igual sentido, a Convenção de Basileia sobre o Controle de Movimentos Transfronteiriços de Resíduos Perigosos e seu Depósito, ratificada pelo Brasil em 1993, fundamentada nos princípios da notificação e do consentimento prévio, estabelece no artigo 4 a proibição da exportação de resíduos perigosos e outros resíduos às partes que tenham proibido a importação de tais resíduos ou que tenham dado consentimento por escrito restringindo a importação. Ademais, consigna a vedação à exportação de resíduos perigosos a grupos de Estados que são Partes pertencentes a uma organização de integração política ou econômica e, particularmente, aos países em desenvolvimento se tiver motivos para acreditar que tais resíduos não serão geridos de forma ambientalmente segura. ${ }^{15}$ Essas restrições visam à redução do movimento de resíduos ao mínimo compatível com o manejo ambientalmente saudável e eficiente. ${ }^{16}$ As partes convencionaram na adoção de um

14 WORLD TRADE ORGANIZATION. Matrix on TradeRelated Measures Pursuant to Selected Multilateral Environmental Agreements. Committee on Trade and Environment. WT/CTE/W/160/Rev.5 of 15 june, 2011. p. 49.

15 Artigo $4^{\circ}$, alínea 2 , e da Convenção de Basileia sobre o Controle de Movimentos Transfronteiriços de Resíduos Perigosos e seu Depósito. Disponível em: < http://www.basel.int/Portals/4/ Basel\%20Convention/docs/text/BaselConventionText-e.pdf $>$. Acesso em: 21 out. 2014.

16 WORLD TRADE ORGANIZATION. Matrix on Trade- 
mecanismo flexível, não contecioso e não vinculativo que promova sua implementação e cumprimento.

Exatamente a contradição existente entre obrigações assumidas perante um sistema jurídico que diretamente influenciam compromissos acordados em outro é o objeto do presente estudo: a interação entre as normas $\mathrm{da} \mathrm{OMC}$ e as normas dispostas nos tratados ambientais que permitam a adoção de medidas restritivas ao comércio em prol da preservação dos ecossistemas.

Assim, conforme visto por tais tratados ambientais multilaterais, o subsistema ambiental impõe sua própria lógica, concretizando valores que busquem minimizar a consequência da liberalização do comércio. Através das cláusulas restritivas ao comércio, os tratados multilaterais ambientais são mecanismos que visam à proteção dos recursos naturais, fornecendo meios para a troca de conhecimentos científicos e informação entre os países-signatários. Sobretudo, caracterizamse por serem regulamentações e normas orientadas à concretização do desenvolvimento sustentável, em virtude de não apresentarem os riscos advindos dos acordos unilaterais e por serem capazes de atuar como soluções multilaterais para os problemas ambientais transfronteiriços, regionais e internacionais. Contudo, adeptos do sistema multilateral de comércio temem que estados protecionistas se utilizem de padrões ambientais para disfarçar as barreiras ao comércio e, também, que se valham de políticas com benefícios mínimos à saúde pública e ao meio ambiente para impor encargos injustificáveis ao comércio.

\subsection{Conflito de jurisdições}

De outro lado, a contrapartida do desenvolvimento de novas redes de responsabilidades e da multiplicação de normas específicas internacionais, impostas pelos subsistemas do direito internacional, também implica a criação de órgãos jurisdicionais capazes de implementar e controlar o cumprimento das obrigações ambientais e comerciais assumidas por parte dos Estados. Assim, percebe-se a emergência de diferentes tribunais internacionais aptos a julgar as controvérsias, surgindo também o conflito entre jurisdições.

Em poucos anos, o número de tratados, tribunais e, consequentemente, de jurisdições aumentou

Related Measures Pursuant to Selected Multilateral Environmental Agreements. Committee on Trade and Environment. WT/CTE/W/160/Rev.5 of 15 june, 2011. p. 64. dramaticamente, representando positivamente o aprimoramento na interpretação das normas, criando um corpo de julgadores mais eficientes e precisos. De fato, a proliferação de tais tribunais indica a edificação de uma ordem internacional fundamentada nos ideais de justiça, de independência e de legitimidade dos sistemas jurídicos.

Um conflito de jurisdição, no sentido de haver a sobreposição de tribunais ou diversos mecanismos de solução de controvérsias para julgar um mesmo fato, pode ser manejado quando um tratado ambiental préexistente à promulgação dos acordos da OMC em 1994 continua a ser relevante entre os membros da OMC os quais devem obedecê-lo. Da mesma forma, todos os novos tratados criados entre alguns ou todos os membros da OMC, posteriormente à conclusão dos acordos da OMC (diga-se, o Protocolo de Cartagena sobre Biossegurança ou as recentes Convenções das Nações Unidas), necessariamente, interagem com os direitos e obrigações dos membros da OMC vinculados ao novo tratado.

Assim, enquanto o desenvolvimento das relações internacionais conduziu a uma maior produção normativa e ao crescimento do número de organizações internacionais para tratar de questões técnicas, econômicas e sociais, consequentemente, abriu espaço para criação de novos sistemas de solução de controvérsias. ${ }^{17}$ A proliferação de tribunais, nesse sentido, vem a estimular a criatividade e a interação do direito através do diálogo entre diferentes áreas.

Todavia, a falta de coerência entre as técnicas de interpretação pode resultar em diferentes posicionamentos dos órgãos jurisdicionais internacionais, particularmente no momento do confronto entre o comércio e o meio ambiente.

$\mathrm{Na}$ presença de obrigações conflitantes dispostas em tratados diferentes, procura-se encontrar maneiras de coordenar simultaneamente os direitos assegurados em cada um dos subsistemas, mas não prorrogando a solução para o futuro, por meio de cláusulas condicionais. O Protocolo de Cartagena sobre Biossegurança, ao assegurar que tratados sobre comércio e meio ambiente amparam-se mutuamente com o fim de atingir o desenvolvimento sustentável, reconhece que conflitos devem ser instaurados e

17 KINGSBURY, Benedict. Is the proliferation of International Courts and Tribunals a Systemic Problem? The New York University Journal of International Law and Policy. v. 31, p. 681, 1999. 
resolvidos entre as partes, mas não pontua de forma clara como ocorrerão as negociações e procedimentos. ${ }^{18}$

São inúmeros os exemplos ${ }^{19}$ de tratados multilaterais ambientais que seguem essa mesma linha de indefinição quanto à resolução de conflitos, especialmente quando congregam partes de diferentes subsistemas, com também diferentes interesses e objetivos. A não ser que os Estados contratantes concordem previamente na escolha do foro competente para dirimir possíveis controvérsias, é visível a espécie de conflito entre diferentes jurisdições para o caso.

Face à ausência de uma organização mundial ambiental, com poder similar ao que a OMC exerce em matéria comercial, prevalece a descontinuidade e a competição em termos de escolha de jurisdição. De fato, por mais que essa diversidade auxilie a disseminar a efetividade das normas, parece que a multiplicidade de fóruns apropriados a julgar os litígios pode favorecer a primazia da lógica comercial. ${ }^{20}$

Isso abre precedentes para que o órgão escolhido, normalmente representativo de uma das partes e não um órgão terceiro imparcial, julgue o caso de acordo com as prioridades de seu regime, subsistema. Nesses casos, cláusulas ambíguas e abertas acobertam a atuação vantajosa e imparcial conferida a determinado regime em detrimento do outro.

Com efeito, quando em pauta a violação de uma obrigação ambiental ou comercial internacional, mecanismos de cumprimento ou de solução de controvérsias cumprem a função de reforçar os objetivos particulares dos tratados e obstar que a

18 O artigo 24 Protocolo de Cartagena sobre Biossegurança expressa, em complementação ao preâmbulo que reconhece que tratados sobre comércio e meio ambiente devem ser interpretados de maneira harmônica para alcançar o desenvolvimento sustentável, que movimentos transfronteiriços de organismos geneticamente modificados entre partes e partes não signatárias necessitam ser consistentes com o objetivo do presente protocolo, permitindo a celebração de acordos bilaterais, regionais e multilaterais. Para acessar o texto do Protocolo, ver: <http://bch.cbd.int/protocol/ text/>. Acesso em: 9 set. 2013.

19 Nesse sentido, a Convenção de Diversidade Biológica de 1992, a Convenção de Basileia de 1989 e o Tratado Internacional sobre os Recursos Fitogenéticos para a Alimentação e a Agricultura de 2002 também apresentam cláusulas que estabelecem cooperação mútua entre as diferentes partes contratantes, deixando, entretanto, espaço para interpretação ambígua quanto à apreciação e negociação. Ver: CDI, 2006, p. 140.

20 DELMAS-MARTY, Mireille. Comparative Law and International Law: methods for ordering pluralism. 2005. Disponivel em: $<$ http://w7.ens-lyon.fr/amrieu/IMG/pdf/Delmas-Marty_Comp_ Int_Law_10-05doc.pdf $>$.p. 12. parte transgressora reincida no descumprimento da obrigação. ${ }^{21}$ Isso porque uma correta interpretação quanto às obrigações estatais realiza-se de maneira que partes signatárias da OMC e dos tratados ambientais não procurem mecanismos de resolução de conflitos sem necessidade, dirigindo seus casos às instâncias mais apropriadas.

Portanto, a forma pela qual ocorrerá essa interpretação dos tratados é assunto da parte que segue, haja vista que as normas dos subsistemas ambiental ou comercial, codificadas em instrumento de tratado, podem ser interpretadas à luz do artigo 31 da Convenção de Viena sobre o Direito dos Tratados, a fim de estabelecer uma possível integração entre regimes integrantes do direito internacional, de forma a assegurar a coerência com o ambiente normativo.

\section{Interpretação e integração aplicáveis aos subsistemas do direito internacional}

\subsection{Convenção de Viena sobre o Direito dos Tratados: instrumentos à interpretação}

Não obstante a ocorrência de conflitos ser rechaçada pelo direito internacional, observa-se o crescente número de casos que trazem no seu bojo questões conflituais entre tratados. Em tese, não há hieraquia no direito internacional entre os acordos da OMC e os tratados multilaterais ambientais. Com exceção das normas jus cogens e das obrigações da Carta das Nações Unidas, nenhuma norma de direito internacional pode ser considerada mais importante do que outra. ${ }^{22}$

Visto que toda norma de direito internacional, de um modo ou de outro, deriva da mesma fonte, isto é, do consentimento do Estado, é indiferente a estipulação de uma hierarquia de fontes. $\mathrm{O}$ artigo 38 do Estatuto da Corte Internacional de Justiça, ao prever as fontes de direito internacional aplicáveis às controvérsias, não confere nenhuma ordem de preferência às convenções, aos costumes e aos princípios gerais de direito, expressando a mesma relevância jurídica de tais fontes. Similarmente ao artigo 38, os artigos 3.2 e 7 do ESC,

21 WEISS, Edith Brown et al. International environmental law and policy. Nova York: Aspen Publisher, 2007. p. 177.

22 PAUWELYN, Joost. The application of non-WTO rules of international law in WTO dispute settlement. In: MACRORY, Patrick; APPLETON, Arthur; PLUMMER, Michael (Ed.). The World Trade Organization: legal, economic and political analysis. United States: Springer, 2005. p. 1418. 
no âmbito da OMC, especificam que a controvérsia deve ser solucionada consoante as obrigações dispostas nos acordos constitutivos da OMC. O ESC engloba tão somente medidas que afetem o funcionamento de qualquer dos acordos-quadro dentro do território de um seus membros, incluindo medidas adotadas em nível local ou regional.

Entretanto, sob a análise do artigo 38 da CIJ, é possível asseverar que a OMC não descarta o sistema geral de direito internacional, aplicando princípios e regras aos seus litígios, fazendo-o em conformidade com o artigo 3.2 do ESC. ${ }^{23}$ Especificamente a abertura oferecida por esta disposição permite adequar a complexidade existente entre dois subsistemas do direito internacional, superando o antagonismo de normas que se encontravam fechadas e seladas ao seu próprio regime.

Justamente pela inexistência de hierarquia entre as normas que reside o desafio de encontrar o adequado equilíbrio entre direitos potencialmente conflitantes. Da indagação sobre se os órgãos jurisdicionais da OMC, Painel e Órgão de Apelação podem utilizar outros acordos que não sejam os promulgados pela $\mathrm{OMC}$, como os tratados multilaterais ambientais, responde-se em tom afirmativo pelas razões que seguem.

Quando as normas da OMC não excluam a aplicação de determinada regra, as demais normas de direito internacional continuam a ser aplicáveis. Através do recurso a regras gerais do direito internacional, restou comprovado que, no silêncio de um acordo da OMC, podem sim ser aplicadas as demais normas do direito internacional. ${ }^{24}$ A dizer, Painéis e Órgão de Apelação podem aplicar princípios gerais do direito internacional quando as normas da OMC não vedem expressamente sua aplicação. Afirmar o contrário, que a $\mathrm{OMC}$ não pode considerar normas que não estejam expressamente

23 O artigo 3.2 do ESC que confere comunicação entre as normas da $\mathrm{OMC}$ e as normas consuetudinárias do direito internacional prevê: “[...] Os Membros reconhecem que esse sistema é útil [...] para esclarecer as disposições vigentes dos referidos acordos em conformidade com as normas correntes de interpretação do direito internacional público. As recomendações e decisões do OSC não poderão promover o aumento ou a diminuição dos direitos $\mathrm{e}$ obrigações definidos nos acordos abrangidos." Disponível em: <http://www.wto.org/english/tratop_e/dispu_e/dsu_e.htm>. Acesso em: 17 out. 2013.

24 Nesse sentido, o caso Argentina - Footwear (parágrafo 67) e EC - Hormone (parágrafo 123) ilustram que o Órgão de Apelação não deveria limitar sua análise apenas aos Acordos da OMC, mas frente à ausência de regras de conflitos dispostas nos Acordos, aplicar regras de conflitos relacionadas ao direito internacional. referidas nos seus tratados, é ir contra o princípio básico de que as regras de direito internacional aplicam-se incondicionalmente aos tratados.

Dessa forma, reconhecendo que as normas da OMC são permeáveis às situações externas, tornase necessário analisar a incidência da Convenção de Viena sobre o Direito dos Tratados de 1969 (CVDT) na tentativa de conferir coerência à ordem jurídica internacional.

O texto da Convenção de Viena surge como método útil a fim de integrar os subsistemas ambiental ao comercial, oferecendo soluções para os conflitos aparentes entre normas e revelando a harmonização no ordenamento jurídico plural. Essa permissão é consequência da previsão do artigo 31.3 (c) da CVDT que, ao afirmar que a interpretação de um tratado deve levar em consideração "quaisquer regras pertinentes de direito internacional aplicáveis às relações entre as partes", abrange o escopo de normas possíveis de serem aplicadas pelo corpo jurídico da OMC, incluindo também as normativas dos tratados multilaterais ambientais. Esse artigo é um indicador de que as normas do direito internacional devem ser levadas em conta na interpretação das disposições de tratados específicos, como o da OMC. É considerado, também, como presunção de que os Estados não objetivam promulgar novas normas de direito internacional inconciliáveis com as já existentes.

Conforme observado durante os debates da Comissão de Direito Internacional, ${ }^{25}$ o grupo de estudos ressaltou que o artigo 31.3 (c) dá expressão ao objetivo de "integração sistêmica" do sistema jurídico internacional, descrevendo um processo de raciocínio legal em que elementos particulares terão maior ou menor importância, dependendo da natureza das disposições dos tratados postos à interpretação.

Assim, as regras de interpretação contidas nos artigos 30, 31 e 32 da Convenção de Viena são admitidas como "customary rules of interpretation of public international law" 26 e amplamente utilizadas no regime

25 CDI. Comissão de Direito Internacional da Organização das Nações Unidas. United Nations. Fragmentation of International Law: difficulties arising from the diversification and expansion of international law. Report of the Study Group of the International Law Commission. Finalized by Martti Koskenniemi. April, p. 208, 2006. Disponível em: <http://untreaty.un.org/ilc/documentation/ english/a_cn4_1682.pdf>.

26 Relatório do Painel no caso European Communities - Customs Classification of Frozen Boneless Chicken Cuts, WT/DS269/R, julgado em 30 de maio de 2005. parágrafo 7.88. Em igual sentido ver 
da OMC. Em que pese haver alguns membros da OMC que não sejam também partes-signatárias da Convenção de Viena sobre Direito dos Tratados de 1969, o Órgão de Apelação, seguindo precedentes da Corte Internacional de Justiça (Iran v. US, 2003, para. 4.1) declarou que a Convenção representa a codificação das regras de direito internacional consuetudinário, portanto, obrigatória para todas as partes signatárias dos acordos abrangidos da OMC.

Especificamente, tais artigos foram incorporados pelos acordos da OMC na seção relativa ao ESC. O artigo 3.2 do ESC, ao preservar direitos e obrigações de seus membros, dispõe que o Painel e Órgão de Apelação deve clarificar as disposições da OMC em consonância com as normas consuetudinárias de interpretação do direito internacional. O Órgão de Apelação, ao decidir o caso US - Continued Zeroing ${ }^{27}$ demonstrou como o referido dispositivo deve ser aplicado em conformidade com preceitos do processo interpretativo da Convenção de Viena. Ressalta-se que neste caso o Órgão de Apelação elucidou que os elementos para interpretação dos tratados dispostos nos artigos $31 \mathrm{e}$ 32 não expressam uma estrutura de hierarquia, pois são indistintamente partes integrantes e essenciais do processo interpretativo.

No entanto, vige a vedação ao acréscimo, diminuição ou alteração de direitos e obrigações nos acordos-quadro da OMC, obstando a extensão de competência do Órgão de Solução de Controvérsia, conforme previsto no final do art. 3.2 do ESC. A solução para este ponto é a de que a análise dos tratados multilaterais ambientais feita pelos Painéis não se estenda em determinar se a medida comercial violada enquadra-se nos termos do tratado ambiental. A análise deve repousar somente na verificação de se as partes signatárias do regime da OMC também o são do referido tratado multilateral ambiental e se o alegado tratado ambiental contém regras relevantes de direito internacional aplicáveis às partes.

Entretanto, de acordo com Trachman, ${ }^{28}$ as normas de direito internacional que não estão expressas nos

$\overline{\text { julgamento do Painel e Órgão de Apelação em casos como Japan }}$ - Alcobolic Beverages, Carbon Steel, US - Gasoline que reconheceram a funcionalidade dos artigos 31 e 32 da Convenção de Viena na estipulação de regras de interpretação ao direito internacional.

27 Relatório do Órgão de Apelação no caso United States Continued Existence and Application of Zeroing Methodology, WT/DS350/ $\mathrm{AB} / \mathrm{R}$, julgado em 4 de fevereiro de 2009. parágrafo 268 .

28 TRACHTMAN, Joel P. The Domain of WTO Dispute Resolution. acordos da OMC não deveriam ser utilizadas na interpretação das resoluções de controvérsias. Esta visão vai contra e distancia-se de diversas decisões proferidas pelo Painel e pelo Órgão de Apelação que fazem referência a normas contidas em outros tratados. No seu primeiro relatório do caso US-Gasoline $e^{29}$, o Órgão de Apelação ponderou que os acordos da OMC não devem ser interpretados em "clinical isolation" do direito internacional público.

Neste propósito, dizer que os órgãos da OMC possuem uma jurisdição limitada para interpretar e aplicar os acordos abrangidos não significa que as normas da OMC devam ser aplicadas de forma isolada do resto do direito internacional, ${ }^{30}$ reconhecendo, ademais, que os costumes internacionais aplicam-se aos acordos entre os Estados membros da OMC.

Tal como foi no caso US-Shrimp ${ }^{31}$, no qual o Órgão de Apelação recorreu ao auxílio de textos de outros tratados, como a CDB e a CITES, para interpretar termos próprios do comércio internacional. No referido caso, o Órgão de Apelação interpretou o termo "recursos naturais exauríveis" disposto no artigo XX (g) do GATT. Mais uma vez, se a resolução de litígios da OMC fosse somente restrita a cláusulas de seus tratados, esta referência aos tratados multilaterais ambientais não teria sido possível.

p. 5, 1999. Disponível em: <http://ssrn.com/abstract=149348>.

29 Ao explicar o artigo 31 da Convenção de Viena sobre Direito dos Tratados, o Órgão de Apelação consignou que: "That general rule of interpretation has attained the status of a rule of customary or general international law. As such, it forms part of the "customary rules of interpretation of public international law" which the Appellate Body has been directed, by Article 3(2) of the DSU, to apply in seeking to clarify the provisions of the General Agreement and the other "covered agreements" of the Marrakesh Agreement Establishing the World Trade Organization (the "WTO Agreement"). That direction reflects a measure of recognition that the General Agreement is not to be read in clinical isolation from public international law Relatório do Órgão de Apelação no caso United States - Standards for Reformulated and Conventional Gasoline, WT/ $\mathrm{DS} 2 / \mathrm{AB} / \mathrm{R}$, adotado pelo Órgão de Solução de Controvérsias em 22 de abril de 1996. p. 17.

30 MARCEAU, Gabrielle. A Call for Coherence in International Law: praises for the prohibition against "clinical isolation" In WTO Dispute Settlement. Journal of World Trade, Holanda, v. 33, n. 5, p. 131, 1999.

31 Trata-se de um caso postulado pela Índia, Paquistão, Tailândia e Malásia contra a atitude do governo dos Estados Unidos de proibir a importação de camarão em virtude dos métodos utilizados na sua captura, que ameaçavam a vida das tartarugas marinhas. Vide: Relatório do Órgão de Apelação no caso United States - Import Probibition of Certain Shrimp and Shrimp Products, WT/DS58/AB/R, 12 de outubro de 1998. 
Logo, encontrar a compatibilidade entre regimes plurais e dotados de objetivos antagônicos não é uma tarefa fácil, ainda mais diante da circunstância de um conflito entre disposições de tratados diferentes e tendo que determinar qual delas irá prepondar sobre a outra. Assim, verificou-se que a OMC pode recorrer a normas consuetudinárias e constantes em outros tratados para embasar sua decisão, desde que não implique no acréscimo ou restrição das obrigações de seus Estados membros, concluindo-se acerca da viabilidade de um Painel ou Órgão de Apelação poderem levar em consideração regras consideradas alienígenas, diferentes daquelas dispostas pelos acordos da OMC, de forma a melhor conceder a aplicação do direito internacional ao caso em concreto.

\subsection{Aplicação do desenvolvimento sustentável como diretriz interpretativa}

A partir do momento em que a OMC avocou maior número de competências para questões além das comerciais, seus mecanismos de resolução de controvérsias não poderiam mais interpretar todas obrigações por meio de "lentes" unicamente sensíveis ao compromisso da liberalização multilateral do comércio. ${ }^{32}$ Especialmente no que tange aos tratados ambientais, sugere-se que Painéis e o Órgão de Apelação façam uso, por exemplo, das ferramentas de interpretação dos tratados também por meio da aplicação do princípio do desenvolvimento sustentável.

Desenvolvimento sustentável aqui entendido como diretriz que se desenvolveu de uma aspiração meramente política para um conceito jurídico que considera as necessidades econômicas, sociais e ambientais da sociedade, tornando-se, assim, um princípio maleável de acordo com circunstâncias particulares. ${ }^{3}$

Depreende-se que a introdução do conceito de desenvolvimento sustentável é um facilitador para que as regras ambientais possam interagir com regras comerciais e expressa a manifestação de vontade dos membros de não limitar seus efeitos simplesmente às relações de comércio e meio ambiente. $\mathrm{Na}$ verdade, o

32 GUZMAN, Andrew T. Global Governance and the WTO. Harvard International Law Journal. v. 45, n. 2, p. 336, Summer, 2004.

33 MARCEAU, Gabrielle; MOROSINI, Fábio. The status of sustainable development in the law of the world trade organization. In: JUNIOR, Umberto Celli; BASSSO, Maristela; JUNIOR, Alberto Amaral (Coord.). Arbitragem e comércio internacional: estudos em homenagem a Luiz Olavo Baptista. São Paulo: Quartier Latin, 2013. p. 60 . meio ambiente tornou-se uma das correntes principais à efetiva integração do comércio. Essa referência claramente demonstra o intuito de não restringir os efeitos do comércio sobre o meio ambiente natural, evidenciando que o princípio do desenvolvimento sustentável está remodelando a interpretação da OMC acerca dos tratados internacionais. ${ }^{34}$

Nesse contexto, a referência ao desenvolvimento sustentável na decisão do Órgão de Apelação desponta como precedente de que o princípio concede "colour, texture and shading" ${ }^{35}$ aos direitos e obrigações dos Estados membros da OMC, ampliando a interpretação baseada nas circunstâncias do Acordo Geral da OMC. Trata-se de clara indicação ao reconhecimento do desenvolvimento sustentável como princípio informador das intenções dos membros em todos os acordos abrangidos da OMC.

De forma a acompanhar o caráter evolutivo ambiental e de maneira a atingir uma interpretação coerente com o desenvolvimento sustentável, o Órgão de Apelação precisou recorrer ao auxílio de alguns tratados e declarações multilaterais ambientais - mesmo que nem todos os Estados membros da OMC também o fossem de tais tratados e declarações. Os referidos diplomas ambientais - entre os quais está a Declaração sobre Desenvolvimento e Meio Ambiente do Rio de Janeiro, a CITES e a CDB - expressavam preocupações comuns dos governos.

Em especial, a referência à Declaração do Rio de Janeiro de 1992 foi feita por ocasião do julgamento do caso US - Shrimp, quando o Órgão de Apelação, analisando a adoção de medidas unilaterais por parte de seus membros, concluiu que a disposição do princípio 12 da Declaração do Rio seria o canal de justificação de certas ações unilaterais para proteger o ambiente externo à jurisdição nacional. Dessa forma, o Órgão de Apelação utilizou esse princípio como argumento para rebater a alegação americana, fazendo uso de "normas

34 MOROSINI, Fábio. Trade and Climate Change: unveiling the principle of common but differentiated responsibilities from the WTO Agreements. The George Washington International Law Review, Washington, v. 42, n. 4, p. 717, 2010.

35 O Órgão de Apelação no relatório do julgamento US Shrimp, em 1998, concluiu que a que a referência ao desenvolvimento sustentável no preâmbulo da OMC concede cor, textura e delineamento aos direitos e obrigações dos membros sob os Acordos da OMC. Relatório do Órgão de Apelação no caso United States - Import Probibition of Certain Shrimp and Shrimp Products, WT/ DS58/AB/R, 12 out. 1998. Disponível em: < http://www.wto.org/ english/tratop_e/dispu_e/58abr.pdf $>$. para. 155. 
ambientais - e não meramente comerciais - para discutir uma restrição ao comércio por outra norma ambiental". 36

Assim, a partir do julgamento desse mesmo caso (US - Shrimp), o Órgão de Apelação interpretou o termo "recursos naturais exauríveis" em harmonia com a exceção feita pelo artigo XX, alínea g do GATT, ampliando a interpretação concedida pelo Painel que havia definido o termo como recursos finitos, não incluindo os ecossistemas biológicos e renováveis. ${ }^{37}$ Nota-se, então, que a interpretação do Órgão de Apelação para estender o termo "recursos naturais não renováveis" de forma a abranger também outros organismos vivos demonstra seu posicionamento em conformidade com as diretrizes do desenvolvimento sustentável.

Além disso, a atividade dos órgãos jurisdicionais da OMC também é norteada consoante o princípio da transparência que subsidia diversos compromissos na área ambiental. A partir do efetivo compartilhamento de informações e da prestação de contas por parte de cada Estado membro, o alcance das políticas públicas comerciais com viés ambiental torna-se menos dispendioso do que o recurso a novas negociações. $\mathrm{O}$ princípio da transparência dita que as partes signatárias devem dar publicidade à negociação e à implementação das obrigações comerciais dispostas nos tratados multilaterais ambientais como forma de melhor examinar as regulamentações ambientais domésticas e seus impactos no comércio internacional. Inclusive, há quem $^{38}$ sustente que o sistema ambiental influenciou e

36 VARELLA, Marcelo Dias. Internacionalização do direito: direito internacional, globalização e complexidade. Brasília: UniCEUB, 2013. p. 238.

37 Nesse sentido, Morosini pondera que desenvolvimento sustentável lapidou a interpretação de diversos termos dos acordos da OMC inserindo a proteção ambiental na agenda comercial. Ver em: MOROSINI, Fábio. Taking into account environmental, social and cultural concerns through the objective of sustainable development: perspectives from the WTO Jurisprudence on General Exceptions In: HANANIA, Lilian Richieri (Org.). Effectiveness and normativity of the 2005 UNESCO Convention on the Protection and Promotion of the Diversity of Cultural Expressions. Londres: Routledge, 2014. p. 54.

38 Charnovitz assevera que o debate comércio e meio ambiente imprimiu amplo impacto nos procedimentos da OMC. Segundo a visão deste autor, a crítica dos ambientalistas e de ONGs foi fundamental para que, no início dos anos 90, a liderança dos burocratas comerciais concedessem abertura ao sistema de negociação como resposta à influência dos ambientalistas no sistema comercial. Nesse sentido, ver: CHARNOVITZ, Steve. Trade and the Environment in the WTO. GWU Legal Studies Research Paper n. 338. p.10, 2007. Disponível em: <http://ssrn.com/abstract=1007028>. exportou normas a favor da transparência organizacional à OMC, já que a solução de controvérsias do GATT carecia de certa quantidade de transparência. ${ }^{39}$

O glossário da OMC define transparência como o nível de abertura e previsibilidade estabelecido nas políticas e práticas comerciais. Tal previsibilidade refere-se ao conhecimento prévio de todas as medidas de defesa comercial que poderão ser utilizadas pelos membros da OMC, a exemplo de barreiras não tarifárias visíveis e mensuráveis. Destaca-se que a participação da sociedade é condição essencial para que as normas dos subsistemas comercial e ambiental sejam consideradas transparentes e confiáveis. Com efeito, a transparência, além de promover uma maior inserção da sociedade na elaboração de normas e na fiscalização de seu cumprimento, incentiva o aumento da eficácia dos acordos da OMC com os compromissos ambientais. ${ }^{40} \mathrm{O}$ princípio da transparência torna-se, então, corolário para o desenvolvimento sustentável, incentivando procedimentos com tomadas de decisões democráticas e com responsabilidade financeira. ${ }^{41}$ Esta transparência é uma oportunidade para acomodar as medidas comerciais de acordo com as obrigações ambientais, partindo do pressuposto de que a maior concessão de informações é capaz de induzir o governo a modificar sua política e superar os obstáculos a partir de sua clara identificação.

Frente a essa percepção, os tratados multilaterais ambientais tornam-se uma via natural de regulação em conjunto com as normas dispostas pela OMC que, em razão de ter incluído a preservação do meio ambiente entre as diretrizes de seu sistema, continua a avançar em harmonia com a promoção do desenvolvimento sustentável.

Desse modo, uma forma apropriada para solucionar os conflitos entre sistemas normativos díspares em reflexo à complexidade da ordem internacional ocorre por meio da integração de regras e conceitos articulados em tais regimes, autônomos e ao mesmo tempo complementares, considerando seus compromissos, na

39 JACKSON, John H. World Trade Rules and Environmental Policies: congruence or conflict? Washington and Lee Law Review. v. 49, n. 4, p. $1255,1992$.

40 HALLE, Mark; WOLFE, Robert. A new approach to transparency and accountability in the WTO. Entwined. Issue Brief 6, 2010. p. 3.

41 SEGGER, Marie-Claire Cordonier; KHALFAN, Ashfaq. Sustainable Development in Policy and in Law: principle, practices and prospects. USA: Oxford University Press, 2005. p. 101. 
devida medida, com o desenvolvimento sustentável. Resta saber, então, se o regime jurídico da OMC está realmente acompanhando esse padrão ambientalmente sustentável e de que forma excepciona e compatibiliza os objetivos ambientais com o direito internacional comercial, assunto que será pormenorizadamente abordado no próximo ponto.

\section{Conciliando medidas restritivas do comércio e objetivos ambientais}

\subsection{Premissas do artigo XX do GATT 1994}

A exemplo de um regime associado à fragmentação do direito internacional, a OMC, em período relativamente recente, tem promovido esforços para demonstrar que a relação entre os objetivos da salvaguarda de um sistema multilateral de comércio aberto e não discriminatório pode e deve se apoiar mutuamente com o viés da proteção do meio ambiente e da promoção do desenvolvimento sustentável. Realiza essa tarefa, em grande parte, por meio das restrições comerciais estabelecidas no artigo XX que concede o equilíbrio entre a eliminação das barreiras alfandegárias e a liberdade concedida pelos Estados para tomar decisões que protejam interesses sensíveis à população nacional - como são os problemas ambientais.

A redação do artigo $\mathrm{XX}$ foi pensada quando da formação da Organização Internacional do Comércio e seu dispositivo, especificamente ao que se refere às alíneas (b) e (g), manteve idêntica forma, prevendo que, "desde que não sejam aplicadas de forma a constituir quer um meio de discriminação arbitrária, ou injustificada, entre os países onde existem as mesmas condições, quer uma restrição disfarçada ao comércio internacional, disposição alguma do presente capítulo será interpretada como impedindo a adoção ou aplicação, por qualquer parte contratante, das medidas: b) necessárias à proteção da saúde e da vida das pessoas e dos animas e à preservação dos vegetais; g) relativas à conservação dos recursos naturais esgotáveis, se tais medidas forem aplicadas conjuntamente com restrições à produção ou ao consumo nacionais." Ressalva-se, entretanto, a ponderação proposta pelo Brasil e adotada na Conferência de Genebra em agosto de 1947 para excluir a expressão ${ }^{42}$ que levava

42 A referida expressão da precedente leitura do artigo XX (g) era "taken pursuant to international agreements". Nesse sentido, em consideração tratados internacionais disposta na alínea (g), afastando a exigência de qualquer requisito relativo à conformidade de tais medidas com tratados multilaterais ambientais.

$\mathrm{O}$ artigo XX, então, estabelece a aplicação de medidas ambientais contidas em outros instrumentos do direito internacional, mesmo que restritivas ao comércio. Elenca exceções às regras sobre a liberalização comercial "com o intuito de permitir a execução de políticas governamentais que promovam a realização de finalidades essenciais para as sociedades domésticas." ${ }^{\not 3}$ Por isso, o artigo XX fornece isenções no que tange aos aspectos de grande relevância, como a moralidade pública, saúde humana, vegetal ou animal e a defesa dos recursos naturais.

Apesar de nem mencionar a palavra meio ambiente, visto que, na época de sua redação, em 1947, a degradação ambiental não era motivo de preocupação pública, a função do artigo XX é favorecer o diálogo com os demais subsistemas do direito internacional, designadamente, os tratados multilaterais ambientais. De fato, a proteção do meio ambiente, por meio das sanções dispostas nos tratados multilaterais ambientais, realiza-se quer por intermédio da letra (b) quer pelo recurso à letra $(\mathrm{g})$.

Com efeito, em primeiro lugar, é preciso identificar se o objetivo levado a cabo por meio da medida restritiva comercial se insere no âmbito das políticas previstas nas alíneas do artigo XX do GATT 1994. Isso inclui verificar se os elementos jurídicos elencam-se em algumas das alíneas que visam perseguir objetivos de saúde pública e de preservação dos recursos naturais exauríveis. ${ }^{44}$ Em segundo lugar, procede-se à

CHARNOVITZ, Steve. Exploring the Environmental Exceptions in GATT Article XX. Journal of World Trade, Geneva, v. 3, n. 5, p. 41, 1991. Para uma melhor compreensão da interpretação dos termos do artigo XX e do quadro regulatório da OMC, ver: THORSTENSEN, Vera; OLIVEIRA, Luciana Maria de (Org.). Releitura dos Acordos da OMC como Interpretados pelo Órgão de Apelação. São Paulo: VT Assessoria Consultoria e Treinamento Ltda, 2013.

43 AMARAL JUNIOR, Alberto do. A solução de controvérsias na OMC. São Paulo: Atlas, 2008. p.191.

44 Essa foi a sequência de passos estabelecidos de forma pioneira pelo Painel na decisão US - Tuna II, conhecido como threestep analysis. Em primeiro lugar, o Painel examinou se o objetivo da política ambiental enquadrava-se nas exceções do artigo XX. Após, considerou se a medida vinculava-se à alínea (b) ou $(\mathrm{g})$ do referido artigo. Preenchidas as 2 primeiras etapas, então, passou a verificar se a medida atendia à conformidade do caput do artigo. Ver em: Relatório do Painel no caso United States - Restriction on Imports of Tuna II, DS29/R, julgado em 16 de junho de 1994. Parágrafo 5.12. 
verificação quanto ao caput do Artigo XX, analisando se a medida não conduz a uma discriminação arbitrária ou injustificável entre países ou uma restrição disfarçada ao comércio internacional. ${ }^{45}$

Assim, uma medida alternativa que também pode ser adequada às exceções do artigo XX deve preencher 3 requisitos: ser capaz de alcançar o grau de proteção genuinamente estipulado pelo país que está invocando a exceção; não ser uma medida teórica, mas que possa ser posta em prática e que não imponha ônus indevidamente a outra parte. ${ }^{46}$

Não obstante certos tratados multilaterais ambientais realmente confrontarem tais obrigações consideradas pilares dos acordos da OMC, a aplicação das exceções do artigo XX possibilita considerar os tratados ambientais como consistentes com o regime comercial.

Em essência, o artigo XX progrediu com o fim de representar um mecanismo que permitisse exceções às regras comerciais, contanto que políticas com fins de proteção ambiental e de saúde pública não fossem utilizadas como barreiras ao livre-comércio internacional. Sem sombras de dúvidas, é possível afirmar que, atualmente, quase todas as decisões proferidas pelos órgãos jurisdicionais da OMC que se referem a disputas ambientais têm aproveitado os conhecimentos técnicos científicos e, assim, as decisões mais recentes demonstram um viés ambientalmente favorável.

\subsection{Incidência prática das exceções ao sistema multilateral comercial}

$\mathrm{Na}$ maioria dos casos levados à apreciação e julgamento de Painéis e Órgão de Apelação, as medidas expressas nos tratados ambientais são justificadas

45 Quanto à ordem de verificação da alínea (b), após a fixação da análise em 3 etapas, todos os demais casos da OMC observaram a mesma sistemática, examinando primeiro a conformidade com a alínea, para depois analisar o caput do artigo XX. A exceção se faz pelo caso US - Shrimp no qual o Painel iniciou a análise pelo caput, não chegando a proceder a verificação das alíneas. Já na ordem de verificação da alínea (g), a decisão do caso US - Taxes on automobiles, no mesmo ano do julgamento do US - Tuna II, adotou a análise em 3 etapas, metódico que se seguiu no regime da OMC. Ver: Relatório do Painel no caso United States - Taxes on automobiles, DS31/R, em 11 de outubro de 1994. parágrafo 5.56

46 Relatório do Painel e Órgão de Apelação no caso United States - Standards for Reformulated and Conventional Gasoline, WT/DS2/R, em 29 de janeiro de 1996. p. 17. Nesse sentido, ver: MOROSINI, Fábio. Trade and Climate Change: unveiling the principle of common but differentiated responsibilities from the WTO Agreements. The George Washington International Law Review, Washington, v. 42, n 4, p.716, 2010. ao abrigo das exceções da OMC relacionadas à saúde e ao meio ambiente. As alíneas (b) e (g) são as mais contestadas pelo mecanismo de solução de controvérsias da OMC, comprovando-se pela vasta jurisprudência acerca das medidas sobre saúde pública, sanções e proteções normativas compatíveis com o regime comercial e relativas à conservação dos recursos naturais exauríveis.

Durante o regime estipulado pelas regras do GATT, 6 painéis envolvendo questões ambientais foram instaurados (US - Canadian Tuna; Canada - Salmon and Herring; Thailand - Cigarettes; US - Tuna IMexico; US TunaII; US - Automobiles). Percebe-se que, nesse período, as causas submetidas à apreciação do mecanismo de solução de controvérsias do GATT eram julgadas desfavoravelmente à preservação dos recursos naturais ou até mesmo disposições sobre a proteção da natureza não eram sequer consideradas.

Exatamente no caso US - Tuna I também conhecido como caso Atum-Golfinho I, o Painel conferiu prioridade às regras do livre-comércio sobre as normas de proteção ambiental, considerando que a manutenção da solidez de um sistema multilateral de comércio seria mais importante do que a necessidade de proteger os recursos naturais de qualquer país. O caso retratou o embargo americano sobre o atum proveniente do México, envolvendo acidentalmente uma significante captura de golfinhos no momento da pesca do peixe. A legislação dos Estados Unidos, Marine Mammal Protection Act, requeria que os pescadores norte-americanos ajustassem suas práticas pesqueiras para evitar a morte dos golfinhos e proibiu a importação de atum dos países nos quais o índice de mortalidade dos golfinhos superasse em vinte e cinco por cento o de atuns. ${ }^{47} \mathrm{Em}$ decorrência do banimento à importação do atum de seus países, México e Venezuela, em 1990, levaram a disputa ao GATT, obtendo decisão favorável em prol de seus objetivos comerciais em 1991. Isso porque o Painel afirmou que a alegação da conduta americana ter sido motivada na preservação de seus recursos naturais não foi suficiente comprovada para se enquadrar nas exceções do artigo XX, uma vez que a medida não era "destinada principalmente à" conservação, bem como não "relacionava-se com" a conservação e preservação dos recursos naturais, requisitos específicos do artigo $\mathrm{XX}(\mathrm{g})$.

47 Relatório do Painel United States - Restriction on Imports of Tuna, DS21/R - 39S/155, julgado em 3 setembro de 1991. Parágrafo 2.4. 
O Painel também ponderou que os Estados Unidos não poderiam usar as exceções do artigo XX para regular recursos naturais para além de suas fronteiras, expressando a vontade das partes contratantes do GATT, como terceiros interessados, de que o texto do Acordo Geral não poderia sofrer ampliação, permitindo medidas unilaterais. ${ }^{48}$ Caso fosse esta a intenção das partes, deveriam alterar suas normas diretamente através do processo legislativo, por meio de emendas às provisões do Acordo Geral ou de renúncias às correspondentes obrigações, mas não por meio da interpretação do artigo $\mathrm{XX}{ }^{49}$

Assim, enquanto o relatório do Painel no caso US - Tuna I rejeitou o argumento norte-americano para aplicação extraterritorial das exceções (b) e (g), no caso US - Tuna $I I^{50}$ promovido pelas Comunidades Europeias contra os Estados Unidos no ano de 1992, observou-se que o artigo XX (g) sobre conservação de recursos naturais exauríveis não limita a localização das fontes que devem ser preservadas, permitindo, assim, a aplicação da jurisdição extraterritorial. O progresso deste julgamento centrou-se na possibilidade concreta de que uma política de conservação ambiental adotada em determinado país e com difusão de seus efeitos para outras nações possa recair no âmbito das exceções previstas no artigo XX.

Entretanto, as decisões do mecanismo de controvérsias do GATT demonstravam ser tão controversas que muitas não eram adotadas e perseguidas pelas partes, a exemplo das decisões dos casos citados acima. Em análise a esses julgados, pondera-se que, apesar da não obtenção de êxito dos Estados Unidos em justificar suas medidas ambientais

48 Parágrafo 5. 32: "The Panel considered that if the extrajurisdictional interpretation of Article XX(g) suggested by the United States were accepted, each contracting party could unilaterally determine the conservation policies from which other contracting parties could not deviate without jeopardizing their rights under the General Agreement. The considerations that led the Panel to reject an extrajurisdictional application of Article XX (b) therefore apply also to Article XX (g)." Ver também: JACKSON, John H. World Trade Rules and Environmental Policies: congruence or conflict? Washington and Lee Law Review. v. 49, p. 123, 1992.

49 SANTOS, Alvaro. Carving Out Policy Autonomy for Developing Countries in the World Trade Organization: the experience of Brazil and Mexico. In: TRUBEK, David M.; GARCIA, Helena Alvair; COUTINHO, Diogo R et al (ed.) Law and the New Developmental State: The Brazilian Experience in Latin American Context. Cambridge: Cambridge University Press, 2013. p. 193.

50 Relatório do Painel no caso United States - Restriction on Imports of Tuna, DS29/R, julgado em 16 de junho de 1994. nos ditames do artigo XX (g), eis que realmente encontravam-se em violação com as normas do regime comercial, conseguiu avançar em termos de políticas domésticas ambientais. Justamente pelo fato dos Estados Unidos ser considerado ator com reiterada participação no procedimento de solução de controvérsias, desfruta dos benefícios da expertise, do conhecimento rebuscado sobre o funcionamento do sistema judicial e da capacidade de barganha que lhes permitiu alcançar a melhor alternativa para a solução de seu interesse. ${ }^{51}$

A partir da estipulação de novos padrões no mecanismo de solução de controvérsias da OMC, percebeu-se uma positiva e environmental-friendly linha divisória com a precedente jurisprudência do GATT. Desde então, o órgão de solução de controvérsias já foi instado a indiretamente se pronunciar acerca de uma série de disputas envolvendo medidas comerciais relacionadas ao meio ambiente.

O primeiro caso que desafiou as normas da OMC com fundamento na violação da preservação do meio ambiente foi o US - Gasoline. In casu, Brasil e Venezuela contestaram a validade da legislação Fuels and Fuel Additives - Reformulated and Conventional Gasoline da Parte 80 do Título 40 da Legislação Federal Clean Air Act que impôs condições diferenciadas à venda e ao acesso da gasolina importada. Segundo os Estados Unidos, a medida visava ao controle da poluição tóxica causada pela combustão da gasolina fabricada por outros países e sua atitude estaria amparada na exceção da aliena (b) do artigo XX, uma vez que medidas voltadas à promoção da qualidade do ar influenciariam a preservação do meio ambiente.

O Painel concluiu que o artigo XX poderia ser aplicado se os Estados Unidos comprovassem não haver outra medida de igual eficiência e menor efeito restritivo ao comércio que levasse aos mesmos objetivos da emenda ao Clean Air Act - de redução dos poluentes advindos da combustão da gasolina. Os Estados Unidos, no entanto, não conseguiram provar a essencialidade de tal medida, motivo pelo qual o Painel postulou pelo não enquadramento aos

51 SANTOS, Alvaro. Carving Out Policy Autonomy for Developing Countries in the World Trade Organization: the experience of Brazil and Mexico. In: TRUBEK, David M.; GARCIA, Helena Alvair; COUTINHO, Diogo R et al (Ed.) Law and the New Developmental State: The Brazilian Experience in Latin American Context. Cambridge: Cambridge University Press, 2013. p. 188. 
requisitos do Artigo XX e pela violação ao princípio da igualdade de tratamento, tendo em vista que os produtos importados tinham tratamento diferenciado dos nacionais. O Órgão de Apelação chegou à conclusão de que a medida era incompatível com as obrigações assumidas pelos Estados Unidos perante a OMC por constituir discriminação injustificável, mas discordou do relatório do Painel que afirmou que a legislação do Clean Air Act não se enquadrava nos termos do Artigo XX (g). ${ }^{52}$ De fato, a análise do caráter arbitrário e injustificável da medida contestada não está na hierarquização comércio/meio ambiente; apoiase, na ausência de iniciativas e negociações por parte dos Estados Unidos que objetivavam nada além de "favorecer suas próprias indústrias, utilizando o meio ambiente como desculpa." 53

Logo, consagrou-se o entendimento de que medidas voltadas à preservação da natureza podem se expandir para o âmbito extraterritorial, porém a responsabilização apenas recai sobre os nacionais do Estado promulgador da medida. Dessa forma, tendo os Estados Unidos falhado ao demonstrar a necessidade da legislação aos seus nacionais, comprovaram a discriminação a países terceiros, justificando que não poderiam aplicar medidas restritivas à gasolina brasileira.

Já no julgamento em 1998 do caso US - Shrimp ${ }^{54}$ o Órgão de Apelação fixou que os elementos jurídicos da alínea (g) deveriam passar pela análise dos seguintes requisitos: verificar se a medida objetiva ou preocupa-se com a conservação dos recursos naturais; se a medida relaciona-se com a conservação dos recursos naturais exauríveis e se a medida é efetivada em conjunto com restrições à produção ou ao consumo nacional. Ademais, concretizou-se o entendimento de que uma inversão na ordem de primeiro analisar os parágrafos para depois proceder ao estudo do caput do artigo XX poderia conceder interpretação errônea ao WTO Agreement, diminuindo a importância das restrições

52 Relatório do Órgão de Apelação no caso United States Standards for Reformulated and Conventional Gasoline, WT/DS2/AB/R, adotado pelo Órgão de Solução de Controvérsias em 22 de abril de 1996. p. $29-30$.

53 VARELLA, Marcelo Dias. Direito internacional econômico ambiental. Belo Horizonte: Del Rey, 2003. p. 268.

54 Relatório do Órgão de Apelação no caso United States - Import Probibition of certain shrimp and shrimp products, WT/DS58/AB/R, adotado pelo Órgão de Solução de Controvérsias em 6 de novembro de 1998. Parágrafo 127. estabelecidas e desequilibrando direitos e obrigações dos Estados membros. ${ }^{55}$

O referido caso versava sobre o embargo americano imposto à importação de camarões e seus derivados em virtude dos métodos utilizados na sua captura, que ameaçavam a vida das tartarugas marinhas. Por meio da promulgação da Seção 609 da Lei Pública 101-162, os Estados Unidos estabeleceram normas aplicáveis a todos os barcos de pesca de camarão para que utilizassem outros dispositivos além da rede de arrasto de forma a não prejudicar as tartarugas. Segundo o governo dos Estados Unidos, essa medida exigia que todo camarão importado pelos Estados Unidos estivesse em conformidade com a certificação da Seção 609 e, em última análise, era necessária à preservação dos recursos naturais exauríveis, entre os quais se enquadram as tartarugas marinhas. Os países exportadores de camarão como Índia, Paquistão, Tailândia e Malásia insurgiram-se contra a atitude do governo dos Estados Unidos, alegando que tal medida não estaria justificada sob o abrigo do Artigo XX (b) e (g), uma vez que o histórico da produção legislativa da restrição americana demonstrava que o objetivo da medida era tão somente proteger sua indústria pesqueira. Ainda, tais países questionavam o porquê de os Estados Unidos não terem recorrido primeiramente aos instrumentos de política de proteção ambiental, como os meios diplomáticos, atestando sua predisposição em não negociar ou ao menos tentar chegar a um acordo seriamente com os países que exportavam camarão.

O Painel decidiu que a alegação americana não preenchia os requisitos do Artigo XX, além da Seção 609 claramente impor restrições quantitativas aos direitos de exportação, demonstrando ser incompatível com o Artigo XI. Já o Órgão de Apelação, por meio do teste de meios e fins, verificou que o embargo realmente objetivava a conservação das tartarugas, justificando-se a utilização da exceção do Artigo XX (g) $\cdot{ }^{56}$ Entretanto, os Estados Unidos erraram ao ter adotado medidas de conservação às tartarugas marinhas de maneira unilateral e, quanto a esse aspecto, o Órgão de Apelação

55 Relatório do Órgão de Apelação no caso United States - Import Probibition of certain shrimp and shrimp products, WT/DS58/AB/R, adotado pelo Órgão de Solução de Controvérsias em 6 de novembro de 1998. Parágrafo 119.

56 Relatório do Órgão de Apelação no caso United States - Import Probibition of certain shrimp and shrimp products, WT/DS58/AB/R, adotado pelo Órgão de Solução de Controvérsias em 6 de novembro de 1998. Parágrafo. 137 e 142. 
entendeu que os Estados Unidos agiram de modo discriminatório.

Nesse julgado, o Órgão de Apelação teve a oportunidade de estabelecer os parâmetros para a interpretação do Artigo XX, revendo as conclusões auferidas no emblemático caso US - Gasoline. Asseverou não haver hierarquia entre as duas exceções ambientais contidas nas letras (b) e (g) e os artigos I e III do GATT, entendendo que não há, no plano interpretativo, primazia das regras comerciais sobre as exceções concebidas para garantir a preservação do meio ambiente.

Delineando um paralelo a partir do julgamento do caso US - Tuna I até o relatório do Órgão de Apelação em US - Shrimp, é possível perceber o crescimento do número de litígios nos quais questões ambientais são confrontadas com o regime comercial. Isso é reflexo de uma maior inquietação quando o assunto da liberalização do comércio possa tornar mais difícil aos países a manutenção de rigorosos requisitos ambientais.

Portanto, acredita-se que, devido à natureza permissiva do artigo XX, na maior parte dos casos, medidas restritivas dispostas em tratados multilaterais ambientais são compatíveis com as normas da OMC, possibilitando a comunicação e o inter-relacionamento entre os dois regimes que coexistem no ordenamento jurídico internacional. Por essa razão, o artigo XX autorizaria tais restrições. O Órgão de Apelação ${ }^{57}$ afirmou que, na avaliação da interpretação e aplicação do artigo XX, há a necessidade de manter um "equilíbrio" entre as disposições referentes ao meio ambiente e ao comércio, contrabalanceando os direitos e as obrigações dos membros de ambos os subsistemas. Em igual sentido, o Órgão de Apelação ${ }^{58}$ asseverou que

57 Parágrafo 145: “[...] We consider that it embodies the recognition on the part of WTO Members of the need to maintain a balance of rights and obligations between the right of a Member to invoke one or another of the exceptions of Article XX [...]" Relatório do Órgão de Apelação no caso United States - Import Probibition of certain shrimp and shrimp products, W'T/DS58/AB/R, adotado pelo Órgão de Solução de Controvérsias em 6 de novembro de 1998.

58 No caso US-Gasoline, como visto anteriormente, Venezuela e Brasil alegaram que um regulamento dos Estados Unidos discriminava a importação de gasolina e estaria em violação aos princípios da nação mais favorecida e do tratamento nacional, dispostos nos artigos I e III do GATT. Em 1996, o Órgão de Apelação através de uma interpretação teleológica inovadora decidiu que os Estados membros tem autonomia para determinar suas próprias políticas ambientais, circunscrita somente a necessidade de respeitar as exigências do GATT. Nesse sentido ver: < http://www. os acordos da OMC não podem ser entendidos sem levar em consideração o direito internacional público.

\section{Conclusão}

A sustentação de que os múltiplos subsistemas dialogam entre si e com o sistema jurídico internacional permite, então, a compreensão de que o conflito entre as diversas instâncias jurisdicionais deve buscar, no que for compatível, a flexibilidade entre os mecanismos de solução de controvérsias com vistas ao alcance do desenvolvimento sustentável. Fundamentalmente, prevalece o entendimento de que os métodos para fazer referência a regras não pertencentes ao regime da OMC são também diretrizes para normas dos tratados multilaterais ambientais. Nesse sentido, é possível sustentar que a interpretação dos acordos-quadro da $\mathrm{OMC}$ reivindica referência às normas evolutivas do direito internacional. Tais normas, originariamente não componentes do corpo normativo da OMC, são hábeis a auxiliar na solução da controvérsia envolvendo o comércio internacional.

Assim, de forma a melhor responder às consequências impostas pela complexidade do direito internacional, é incontroverso que os acordos da OMC sejam interpretados consoante os ditames dos tratados multilaterais ambientais. Compreende-se que o artigo 3.2 do ESC orienta o caminho para interpretação das decisões do Painel e do Órgão de Apelação, aceitando a incidência dos métodos interpretativos dispostos na Convenção de Viena de 1969, possibilitando o diálogo e a comunicação entre os subsistemas. Além do mais, percebe-se a relevância de realizar uma interpretação fundamentada no conceito e nos objetivos primordiais do desenvolvimento sustentável que deve ser perseguida em todas as circunstâncias, e não apenas nas situações de conflitos, permeadas pela dúvida e obscuridade.

Com efeito, não obstante a interpretação da OMC acerca desse assunto tão polêmico estar longe de ser definitiva, variando de acordo com circunstâncias particulares, nota-se uma forte tendência de diálogo por parte do organismo internacional comercial com os interesses ambientais, evidenciado a partir da aplicação em caráter evolutivo do artigo XX.

wto.org/english/tratop_e/dispu_e/cases_e/ds2_e.htm>. Acesso em: 7 jun. 2012. 


\section{Referências}

AMARALJUNIOR, Alberto do. A solução de controvérsias na OMC. São Paulo: Atlas, 2008.

BARTELS, Lorand. Jurisdiction and Applicable Law Clauses: Where does a Tribunal find the principal norms Applicable to the Case before it? In: BROUDE, T.; SHANY, Y. (Ed). Multi-Sourced Equivalent Norms in International Law.Oxford: Hart, 2011. p. 115-141.

CDI. Comissão de Direito Internacional da Organização das Nações Unidas. United Nations. Fragmentation of International Law: difficulties arising from the diversification and expansion of international law. Report of the Study Group of the International Law Commission. Finalized by Martti Koskenniemi. April, 2006. Disponível em: <http:// untreaty.un.org/ilc/documentation/english/a_cn4_1682. pdf $>$. Acesso em: 17 abr. 2013.

CHARNOVITZ, Steve. Trade and the Environment in the WTO. GWU Legal Studies Research Pape. n. 338 p. 1-30, 2007. Disponível em: <http://ssrn.com/ abstract $=1007028>$.

DELMAS-MARTY, Mireille. Comparative Law and International Law: methods for ordering pluralism. 2005. Disponivel em: <http://w7.ens-lyon.fr/amrieu/IMG/ pdf/Delmas-Marty_Comp_Int_Law_10-05doc.pdf $>$.

GUZMAN, Andrew T. Global Governance and the WTO. Harvard International Law Journal. v. 45, n. 2, p. 303-351, Summer, 2004.

HALLE, Mark; WOLFE, Robert. A new approach to transparency and accountability in the WTO. Entwined. Issue Brief 6, 2010. p. 1-8.

INTERNATIONAL COURT OF JUSTICE (ICJ). Case concerning Oil Platforms - Islamic Republic of Iran v. United States of America, judment of 6 November, 2003. ICJ Rep 161, para. 4.1. Disponível em: <http:// www.icj-cij.org $/$ docket $/$ sum $=634 \&$ code $=o p \& p 1=3 \& p$ $2=3 \&$ case $=90 \& \mathrm{k}=0 \mathrm{a} \& \mathrm{p} 3=5>$. Acesso em: 24 jun. 2013.

JACKSON, John H. World Trade Rules and Environmental Policies: congruence or conflict? Washington and Lee Law Review. v. 49, n. 4, 1992.

KELLY, Claire. The value vacuum: self-enforcing regimes and the dilution of the normative feedback loop. Michigan Journal of International Law. v. 22, p. 673731, 2001.
KINGSBURY, Benedict. Is the proliferation of International Courts and Tribunals a Systemic Problem? The New York University Journal of International Law and Policy, v. 31, p. 679-696, 1999.

MARCEAU, Gabrielle. A Call for Coherence in International Law: praises for the prohibition against "clinical isolation". In WTO Dispute Settlement. Journal of World Trade. Holanda, v. 33, n. 5, p. 87-152, 1999.

MARCEAU, Gabrielle. Conflicts of Norms and Conflicts of Jurisdictions: The Relationship between the WTO Agreement and MEAs and other Treaties. Journal of World Trade. Holanda, v. 35, n. 6, p. 1081-1131, 2001.

MARCEAU, Gabrielle; MOROSINI, Fábio. The Status of Sustainable Development in the Law of the World Trade Organization. In: CELLI JUNIOR, Umberto; BASSSO, Maristela; AMARAL JUNIOR, Alberto (Coord.). Arbitragem e comércio internacional: estudos em homenagem a Luiz Olavo Baptista. São Paulo: Quartier Latin, 2013. p.59-91.

MOROSINI, Fábio. Trade and Climate Change: unveiling the principle of common but differentiated responsibilities from the WTO Agreements. The George Washington International Law Review. Washington, v. 42, n. 4, p. 713-748, 2010.

MOROSINI, Fábio. Taking into account environmental, social and cultural concerns through the objective of sustainable development: Perspectives from the WTO Jurisprudence on General Exceptions In: HANANIA, Lilian Richieri (Org.). Effectiveness and normativity of the 2005 UNESCO Convention on the Protection and Promotion of the Diversity of Cultural Expressions. Londres: Routledge. p. 54-67.

PAUWELYN, Joost. Conflict of Norms in Public International Law: how wto law relates to other rules of international law. New York: Cambridge University Press, 2003.

PAUWELYN, Joost. The application of non-WTO rules of international law in WTO dispute settlement. In: MACRORY, Patrick; APPLETON, Arthur; PLUMMER, Michael (Ed.). The World Trade Organization: legal, economic and political analysis. United States: Springer, 2005. p. 1405-1425.

SANTOS, Alvaro. Carving out policy autonomy for developing countries in the world trade organization: the experience of Brazil and Mexico. In: TRUBEK, David M.; GARCIA, Helena Alvair; COUTINHO, Diogo R et al (Ed.) Law and the New Developmental State: the brazilian experience in latin american context. 
Cambridge: Cambridge University Press, 2013. p. 167 -245 .

STONEHOUSE, Peter D. A review of WTO and environmental issues. Journal of Agricultural and Environmental Ethics. v. 13, n. 1, p. 121-144, 2000. Disponível em: <http://www.springerlink.com/ content/j4544018955738u9/fulltext.pdf $>$. Acesso em: 22 maio 2012.

THORSTENSEN, Vera; OLIVEIRA, Luciana Maria de. (Org.). Releitura dos Acordos da OMC como interpretados pelo órgão de apelação. São Paulo: VT Assessoria Consultoria e Treinamento Ltda, 2013.

TRACHTMAN, Joel P. The Domain of WTO Dispute Resolution. 1999. p. 1-44. Disponível em: <http://ssrn. com/abstract $=149348>$.

VARELLA, Marcelo Dias. Direito internacional econômico ambiental. Belo Horizonte: Del Rey, 2003.

VARELLA, Marcelo Dias. Internacionalização do direito: direito internacional, globalização e complexidade. Brasília: UniCEUB, 2013.

WEISS, Edith Brown et al. International environmental law and policy. Nova York: Aspen Publisher, 2007.

WORLD TRADE ORGANIZATION. Relatório do Painel no caso European Communities - Customs Classification of Frozen Boneless Chicken Cuts, WT/ DS269/R, julgado em 30 de maio de 2005. Disponível em: <http://www.wto.org/english/ tratop_e/dispu_e/cases_e/ds269_e.htm>. Acesso em: 7 out. 2014.

WORLD TRADE ORGANIZATION. Relatório do Painel European Communities - Regime for the Importation, Sale and Distribution of Bananas, WT/DS27 - R, adotado pelo Órgão de Solução de Controvérsias em 22 de maio de 1997. Disponível em: <http://www. wto.org/english/tratop_e/dispu_e/cases_e/ds27_e. htm>. Acesso em :14 out. 2014.

WORLD TRADE ORGANIZATION. Relatório do Painel no caso United States - Restriction on Imports of Tuna I, DS21/R - 39S/155, julgado em 3 setembro de 1991. Disponível em: < http://www.worldtradelaw.net/ reports/gattpanels/tunadolphinI.pdf $>$. Acesso em: 12 out. 2014.
WORLD TRADE ORGANIZATION. Relatório do Painel no caso United States - Restriction on Imports of Tuna II, DS29/R, julgado em 16 de junho de 1994. Disponível em: $<$ http://www.worldtradelaw.net/reports/gattpanels/ tunadolphinII.pdf>. Acesso em: 12 out. 2014.

WORLD TRADE ORGANIZATION. Relatório do Órgão de Apelação no caso Argentina - Safeguard Measures on Imports of Footwear, WT/DS 121/AB/R, julgado em 14 de dezembro de 1999. Disponível em: <http://www. wto.org/english/tratop_e/dispu_e/cases_e/ds121_e. htm>. Acesso em: 9 set. 2014.

WORLD TRADE ORGANIZATION. Relatório do Órgão de Apelação no caso European Communities Measures Concerning Meat and Meat Products (Hormones), WT/DS26/AB/R, WT/DS48/AB/R, julgado em 16 de janeiro de 1998. Disponível em: <http://www.wto. org/english/tratop_e/dispu_e/cases_e/ds26_e.htm>. Acesso em: 11 out. 2014.

WORLD TRADE ORGANIZATION. Relatório do Órgão de Apelação no caso United States - Continued Existence and Application of Zeroing Methodology, WT/ DS350/AB/R, julgado em 4 de fevereiro de 2009. Disponível em: <http://www.worldtradelaw.net/ reports/wtoab/us-continuedzeroing(ab).pdf $>$. Acesso em: 12 out. 2014.

WORLD TRADE ORGANIZATION. Relatório do Órgão de Apelação no caso United States - Import Probibition of Certain Shrimp and Shrimp Products, WT/DS58/AB/R, 12 de outubro de 1998. Disponível em: <http://www. wto.org/english/tratop_e/dispu_e/58abr.pdf $>$. Acesso em: 10 out. 2014.

WORLD TRADE ORGANIZATION. Relatório do Órgão de Apelação no caso United States - Standards for Reformulated and Conventional Gasoline, WT/DS2/AB/R, adotado pelo Órgão de Solução de Controvérsias em 22 de abril de 1996. Disponível em: <http://www.wto. org/english/tratop_e/dispu_e/cases_e/ds2_e.htm>. Acesso em: 18 out. 2014.

WORLD TRADE ORGANIZATION. Matrix on TradeRelated Measures Pursuant to Selected Multilateral Environmental Agreements. Committee on Trade and Environment. WT/ CTE/W/160/Rev.5 of 15 june, 2011. 
Para publicar na Revista de Direito Internacional, acesse o endereço eletrônico www.rdi.uniceub.br ou www.brazilianjournal.org.

Observe as normas de publicação, para facilitar e agilizar o trabalho de edição. 